\title{
THE IMPACT OF INVESTMENT INCENTIVES ON REGIONAL ECONOMIC GROWTH IN TURKEY: AN EMPIRICAL ANALYSIS
} TÜRKIYE'DE YATIRIM TEŞVIKLERININ BÖLGESEL
EKONOMIK BÜYÜME ÜZERINDEKI ETKISI: AMPIRIK BIRANALIZ

Ersin Nail SAĞDIÇ ${ }^{1}$ Göksel KARAŞ ${ }^{2}$

Fazlı YILDIZ ${ }^{3}$

\section{ABSTRACT}

Regional inequalities continue to be a major barrier preventing economic growth and development, especially for developing countries. Governments' efforts to use public investment incentives in eliminating regional inequalities are among the most frequently implemented policies. From this point of view, this paper examines the impact of regional public investment incentives on regional economic growth in 26 development regions of Turkey over the 2004-2018 period using panel data analysis. The results of this study prove that total regional investment incentives have a positive impact on the economic growth of the regions in Turkey. The results also indicate that the investment incentives for

\footnotetext{
Asst. Prof. Dr., Kütahya Dumlupınar University, Department of Public Finance, Kütahya, Turkey, ersinnailsagdic@dpu.edu.tr, ORCID: 0000-0002-4022-8515

2- Dr., Kütahya Dumlupınar University, Department of International Trade and Finance, Kütahya, Turkey, goksel.karas@dpu.edu.tr, ORCID: 0000-0003-4091-1258

3- Assoc. Prof. Dr., Kütahya Dumlupınar University, Department of Public Finance, Kütahya, Turkey, fazli.yildiz@dpu.edu.tr, ORCID: 0000-0003-1387-7883
}

Gönderim Tarihi/Submitted: 15.04.2021

Revizyon Talebi/Revision Requested: 15.05.2021

Son Revizyon Tarihi/Last Revision Received: 17.06.2021

Kabul Tarihi/Accepted: 22.06.2021

Sorumlu Yazar/Corresponding Author: Sağdıç, Ersin Nail

Atıf/To Cite: Sağdıç, Ersin Nail; Karaş, Göksel and Yildız, Fazlı (2021), The Impact of Investment Incentives on Regional Economic Growth in Turkey: An Empirical Analysis, TCA Journal/ Sayıştay Dergisi, 32 (121): 39-64 https://doi.org/10.52836/sayistay.966483 
the agricultural sector positively affect the agricultural sector, and investment incentives for the industrial sector affect the industrial sector positively, and the investment incentives for the services sector positively affect the services sector in Turkey. On the other hand, it has been statistically proved that the effect of investment incentives for the agricultural sector, which has the lowest share in investment incentives, is more effective than other types of incentives. Therefore, one of the most important results of this study is that agricultural investment incentives are among the main dynamics of agricultural development in Turkey, and that it is the most effective incentive type among investment incentives.

\section{ÖZ}

Bölgesel eşitsizlikler, özellikle gelişmekte olan ülkeler için ekonomik büyüme ve kalkınmanın önünde önemli bir engel olmaya devam etmektedir. Hükümetlerin bölgesel eşitsizliklerin giderilmesinde kamu yatırım teşviklerinden yararlanma çabaları en sık uygulanan politikalar arasında yer almaktadır. Bu bakış açısıyla bu çalışma, 2004-2018 döneminde Türkiye'de 26 kalkınma bölgesinde bölgesel kamu yatırım teşviklerinin bölgesel ekonomik büyüme üzerindeki etkisini panel veri analizi kullanarak incelemektedir. Çalışmanın sonuçları, Türkiye'deki toplam bölgesel yatırım teşviklerinin bölgelerin ekonomik büyümesi üzerinde pozitif bir etkiye sahip olduğunu kanıtlamaktadır. Sonuçlar ayrıca tarım sektörüne verilen yatııım teşviklerinin tarım sektörünü, hizmetler sektörüne verilen yatııım teşviklerinin hizmetler sektörünü ve sanayi sektörüne yönelik teşvik yatırımlarının da sanayi sektörünü pozitif etkilediğini göstermektedir. Diğer taraftan yatırım teşvikleri içerisinde en düşük paya sahip olan tarım sektörüne verilen teşviklerin etkisinin diğer teşvik türlerine göre daha etkin olduğu istatistiksel açıdan ispatlanmıştır. Bu çalışmadan elde edilen en önemli sonuçlardan biri tarımsal teşviklerin Türkiye'de tarımsal gelişmenin temel dinamikleri arasında olduğu ve yatırım teşvikleri arasında en etkin teşvik türü olduğudur.

Keywords: Investment Incentives, Regional Development, Regional Incentives, Government Investments

Anahtar Kelimeler: Yatıım Teşvikleri, Bölgesel Kalkınma, Bölgesel Teşvikler, Kamu Yatırımları

\section{INTRODUCTION}

The impacts of the role of governments in economic activities continue because of their importance among the main economic issues. Within the framework of classical economic theory, the economic role of governments was regarded as an organization that only meets the basic needs of social requirements and collects public income for them until the Keynesian theory found a field of application in economic policies. However, in the framework of this view, the failure to solve the problems that arose in the 1929 Economic 
Depression revealed the importance of the economic role of governments. Following those years, especially Keynesian economic theory became popular, and governments increased their activities in all economic fields. Due to the factors causing market failure today, even within Neo-classical economics, government activities in the economic field are considered necessary, although they are limited. However, considering the efficiency problem in the public sector and the public choice theory, it seems that the economic activities of governments harm the efficient distribution of resources, economic growth and development, and private sector development. Despite this, in the theoretical and empirical literature, the importance of the government's regulatory and preventive economic activities is increasing day by day in both developed and developing countries, especially in regional development and growth policies.

The assumptions and propositions of several economic growth models are taken into account in the economic growth and development policies of developing countries. Among these models, the most theoretically important models are Classical Growth Theories, Harrod-Domar Growth Theory, Neoclassical Growth Theory, and Endogenous Growth Theory. These theories state that growth may occur based on factors such as specialization, division of labour, capital accumulation, technological developments, conversion of passive savings to investments, increasing investment levels, research and development activities, human capital investments, and productivity. Moreover, these theories emphasize that economic growth and development should be realized through public savings and policies. Particularly, regional income disparities, injustice in income distribution, regional imbalances in resource distribution force governments to use public policies.

Developing countries had significant opportunities for economic growth and development with increased globalization, while developed countries, which were more competitive, had opportunities to deepen the growth and development gap with developing countries. In such cases, each country applied various policies to realize their growth in line with their own dynamics. A crucial one of these policies is undoubtedly incentives. Incentives are used by both developed and developing countries on both macro and micro scales. The use of micro scale refers to the regional level. Incentives can be given for the development of any sector or for the elimination of development differences between regions. However, its qualifications should be taken into 
account when applying incentives (Recepoğlu and Değer, 2016). The general objectives of incentives are to ensure efficiency in resource allocation, to ensure development by eliminating regional imbalances, to create employment opportunities, to increase exports, to attract foreign direct capital and to ensure international competitiveness (Karaş and Karaş, 2019). From this point of view, economic growth and regional development are among the economic and social objectives of incentives. Incentives are especially important in ensuring the balance between the regions of countries that have different levels of development. For this reason, incentives are a socio-economic instrument in terms of increasing the welfare level of economically backward regions and realizing their economic development (Koç and Saraç, 2020). Therefore, among the fiscal policies, investment incentive policies have become one of the most important tools today. In general, investment incentives are realized in the form of financial and/or intangible support, assistance, and incentives provided by the public through different methods to ensure that economic activities or regions are more developed than other activities or regions in achieving the targets set within the framework of economic and fiscal policy objectives (OECD, 2001; Selen, 2011). In this way, investment incentives aim both to ensure the optimal use of resources by using the resources of the countries in relevant sectors and regions in line with macroeconomic policies and developing a particular sector or eliminating the development differences between regions (Karaş and Karaş, 2019). Incentives are used intensively by developing and developed countries, although their purposes differ according to development levels. However, when the purpose of use for both groups is analysed, it seems that the main purpose is to provide economic growth and eliminate regional imbalances.

Incentive tools have many types, and one of them is investment incentives. Investment incentives are governmental policies designed to affect the size, location, or sector of investment. The main purpose of investment incentives is to increase economic growth in the long run by reducing the initial cost of an investment and/or increasing its profit-making potential (Ayele, 2006). While investment incentives positively affect economic growth in general, they also negatively affect economic growth (Bartik, 2005). To increase the positive impacts of investment incentives, the benefits should reduce investment costs, create employment, attract foreign capital and eliminate regional imbalances (Sevinç et al., 2016). The regional imbalance is defined as economic and social inequality of opportunity among regions occurring due to 
natural factors, implemented democratic and socio-political policies (Chaudhuri, 2001). Today, regional imbalance is among the most important problems in almost all developed and developing countries. Imbalances among regions lead to immigration, population density differences due to immigration, and waste in resource use. Population density among the regions affects the regions' shares from the central budget, which deepens difference even more. Several policies eliminate or reduce this situation, such as investment incentive policies. Through investment incentives, countries aim to increase investments and production in related regions by shifting resources to less developed regions. As a result, the differences in development between regions decrease.

Elimination of regional imbalances in Turkey has been on the agenda since the 1960s. Moreover, the concept of regional development has been included in development plans. However, the real major developments related to regional developmentwere realized with the adoption of outward-oriented industrialization strategy in Turkey similar to the world in the 1980s. Until 2012, both national and regional incentive policies in the scope of EU membership were followed (Taşdoğan, 2013). According to the new investment incentive system coming into force in Turkey in 2012, six incentive regions were created considering the development level of provinces. There are some regional investment incentives such as customs duty exemption, VAT exemption, corporate tax reduction, social security premium support for employers, land allocation, property tax exemption, and interest rate support within this investment incentive system. There are also incentives such as social security premium support for employees and income tax withholding for the region with the least developed provinces. The differences and divergences in regional economic growth indicators in Turkey are discussed and examined in many studies (Ylldıım et al., 2009; Gömleksiz et al., 2017). Moreover, investment incentives have become the most frequently used fiscal policy implemented after the 1980 s to eliminate regional imbalances.

From this point of view, this study aims to investigate the impacts of regional investment incentives regarded as public expenditures by the government in Turkey on regional economic growth. While several studies in literature perform analyses through convergence model, others make estimations over panel cointegration, panel causality, and OLS model. This study aims to contribute to the literature in many aspects. First, besides the impact of total investment incentives on economic growth, the fact that this study is 
included in the research area within the incentives to economic sectors makes a significant contribution to the literature. Moreover, the study considers main hypotheses such as heteroscedasticity, autocorrelation, and cross-sectional dependence. In this context, it contributes through more consistent estimation results by analysing with a more robust estimator.

The study has the following structure: Section 2 presents a review of existing literature. Section 3 describes the empirical strategy, methodology, and data set. It also presents the empirical results of the analysis. Finally, Section 4 presents the conclusion, policy implications, and agenda for further research.

\section{LITERATURE REVIEW}

Various studies exist in the literature on investment incentives and their economic impacts. Studies can be classified as the ones on the impacts of investment incentives on direct macroeconomic variables and the ones on the impacts of investment incentives on regional development policies. The impacts of the types and compounds of investment incentives on economic variables are also examined in some studies. Investment incentives may directly affect the main economic indicators such as economic growth and development across the country. However, the concentration of resources, production, income, and therefore all economic activities in certain regions in developing countries causes certain regions to develop more and certain regions hardly to develop at all. For that reason, governments consider especially the regional developments and the country's general status while determining the investment incentives. Thus, in many countries, investment incentives are even called regional investment incentives. One of the main reasons for this study is to reveal the impact of investment incentives on the high level of regional differences in Turkey. The relationship between investment incentives, public expenditures, regional differences, and economic growth and development in Turkey has always attracted attention (Tansel and Güngör, 1999; Sağbaş, 2002; Yıldırım et al., 2009; Zeren and Yilancı, 2011; Gömleksiz et al., 2017). For instance, Gömleksiz et al. stated that regional income disparities in Turkey could be eliminated through incentives by the government.

There are many studies in literature regarding regional investment incentives based only on fiscal incentives (Tung and Cho, 2001; Reside, 2007; Cleeve, 2008; Gabe and Kraybil, 2002). Many studies indicated that fiscal incentives provided in 
this context positively affected investments and other economic developments. For instance, Cleeve (2008) reported that investment incentives positively affected foreign direct capital investments. However, studies by Loh (1993) and Reside (2007) concluded that fiscal incentives did not strongly affect regional investments and economic growth. In general, the impacts of investment incentives on economic growth have also been regionally tested (Bondonio and Greenbaum, 2006; Goss and Philips, 1999). For instance, Goss and Philios (1999) found that tax incentives in states for the USA increased economic growth. However, Prilleman and Meirer (2014) determined that tax incentives had no impact on economic growth. The effect of investment incentives on employment in Turkey was examined in the study by Karaalp (2014) and Yanıkkaya and Karaboğa (2017). The results of these studies suggested that investment incentives had a positive impact on employment in general. Studies in the literature generally focused on the impacts of total investments on economic variables. The impacts of sectoral investment incentives on both economic and economic sectors were also considered in some studies (Koç and Saraç, 2020; Cambini and Rondi, 2009). For instance, Cambini and Rondi (2009) identified the positive impact of incentives on the energy sector in European Countries. There are also studies conducted in different country sets and periods (Schalk and Untiedt, 2000; Gabe and Kraybil, 2002, Ayale, 2006; Mohl and Hagen, 2010; Camaioni et al., 2013). For instance, Schalk and Untiedt (2000) found that investment incentives had a positive impact on investments, employment, and growth in West Germany. Gabe and Kraybil (2002) also identified the positive impact on employment and economic growth.

Studies on investment incentives and their economic impacts vary in Turkey. Studies also vary overall and regionally in Turkey. Özand Buyrukoğlu (2017) investigated the impact of investment incentive policies on macroeconomic variables between 1980 and 2012. Their results showed that investment incentives had a positive effect on economic growth and employment. Şaşmaz and Özel (2019) determined that the agricultural sector's fiscal incentives positively affected the agricultural sector in Turkey for the period of 1980-2016. There are also studies examining the economic impacts of investment incentives in Turkey (Ay, 2005; Akan and Arslan, 2008; Hazman, 2010; Yavuz, 2010; Şahin and Uysal, 2011; Taşdoğan, 2013). Yavan (2011), one of the leading studies in Turkish literature, found that the investment incentives had a positive impact on regional economic growth. There are also regional studies examining the effects of investment incentives for Turkey (Karaalp, 2014; Selim et al., 2014; Demirtaş and Aksel, 2018; Baykul et al., 2019). Gerni et al. (2015), Sevinç et al. (2016) and Gömleksiz et al. (2017) determined that the investment incentives had positive impacts on economic 
growth in 26 development regions of Turkey for different years. Sağbaş et al's (2016) study obtained significant findings among the regional studies in Turkey. They determined that investment incentives to manufacturing and agricultural sectors had a stimulating impact on both investments and interregional income disparities. Değer and Recepoğlu (2017) determined that investment incentives positively affected the economic growth for Turkey. Çelik (2017) determined that the incentives to the manufacturing sector had a positive impact on the manufacturing sector in Turkey. Saygll (2020) found that the positive impact of investment incentives on economic growth was only valid for the high-income regions for 81 provinces of Turkey. In addition to these studies, some research on investments incentives were based on survey method for Turkey (Gülmez and Yalman, 2010; Hazman and Kaya, 2018; Ekinci et al. 2019). For example, Ekinci et al. (2019) found that investment incentives had a positive effect on factors such as export volume and labour capacity of firms.

\section{EMPIRICAL FRAMEWORK}

\subsection{Data and Model}

The main purpose of this study is to investigate the impacts of regional investment incentives regarded as public expenditures provided by government on regional economic growth. The analysis covers 26 development regions (NUTS2) classified by TURKSTAT in Turkey over the period of 2004-2018. Fixed investment incentive amounts were derived from the General Directorate of Incentive Applications and Foreign Capital of the Ministry of Industry and Technology, and the regional sectoral GDP levels were derived from TURKSTAT. Turkey's investment incentives are divided into four; namely regional incentives, large-scale incentives, general incentives, and strategic investments. In addition, investment incentives consist of five sub-levels as energy, services, manufacturing, mining, and agricultural incentives ${ }^{4}$. Table 1 summarizes the regional averages of regional investment

4- The relevant investment incentives provided by the government include: general investment incentives (customs duty exemption, VAT exemption), regional investment incentives (customs duty exemption, VAT exemption, corporate tax reduction, social security premium support for employer's and employee's, land allocation, interest rate support, income tax withholding support), strategic investment incentives (customs duty exemption, VAT exemption, corporate tax reduction, social security premium support for employer's and employee's, land allocation, interest rate support, VAT refund) and project based investment incentives (cash support, vat exemption, customs duty exemption, corporate tax reduction up to $200 \%$ of investment expenditures, social security premium support for up to 10 years, income tax withholding support for 10 years, qualified personnel support for up to 5 years, energy support for up to $50 \%$ of energy expenditures for up to 10 years, 10 years interest rate support for up to 10 years, capital contribution up to $49 \%$ of the investment amount, land allocation for 49 years, infrastructure support, purchasing guarantee, facilitation of authorization-permitlicense procedures, VAT refund for building-construction expenditures). 
incentives in Turkey ${ }^{5}$. As illustrated in Table 1, the first five regions produce approximately 60\% of the GDP in Turkey at the regional level. GDP in other 21 regions remains at deficient levels. According to this, regional inequality is high in Turkey. In this sense, the investment incentive policies are highly important for shaping regional development in Turkey. When regional investment incentives are analysed under sub-sectors, the highest investment incentive rate belongs to the manufacturing sector (41\%) while the lowest investment incentive rate belongs to the agricultural sector (2\%). In this period, the shares of investment incentives in total investment incentives were manufacturing (41\%), services (29\%), energy (24\%), mining (5\%), and agriculture (2\%) incentives, respectively.

Table 1: Regional Investment Incentives by Economic Sector in Turkey (\%)

\begin{tabular}{|c|c|c|c|c|c|c|c|}
\hline NUTS2 Code & GDP Rank & Regional GDP & Energy & Services & Manufacturing & Mining & Agriculture \\
\hline TR10 & 1 & 30,38 & 3,92 & 74,38 & 21,63 & 0,06 & 0,01 \\
\hline TR51 & 2 & 9,50 & 4,62 & 41,41 & 48,27 & 5,28 & 0,43 \\
\hline TR31 & 3 & 6,27 & 21,02 & 29,72 & 42,91 & 4,50 & 1,84 \\
\hline TR42 & 4 & 5,61 & 6,69 & 24,00 & 68,37 & 0,23 & 0,71 \\
\hline TR41 & 5 & 5,48 & 5,75 & 16,26 & 74,07 & 2,80 & 1,12 \\
\hline TR61 & 6 & 3,97 & 11,98 & 68,44 & 12,61 & 3,12 & 3,84 \\
\hline TR62 & 7 & 3,82 & 39,19 & 27,85 & 30,50 & 1,39 & 1,06 \\
\hline TR32 & 8 & 3,34 & 37,18 & 32,84 & 22,79 & 4,61 & 2,58 \\
\hline TR33 & 9 & 3,23 & 26,02 & 11,95 & 50,37 & 8,51 & 3,14 \\
\hline TR63 & 10 & 2,44 & 30,49 & 21,36 & 47,15 & 0,38 & 0,62 \\
\hline TR83 & 11 & 2,43 & 34,08 & 22,07 & 34,98 & 6,74 & 2,13 \\
\hline TR72 & 12 & 2,40 & 23,44 & 24,76 & 44,04 & 5,85 & 1,91 \\
\hline TR90 & 13 & 2,37 & 47,68 & 28,51 & 16,32 & 7,00 & 0,50 \\
\hline TR52 & 14 & 2,35 & 19,71 & 16,67 & 58,50 & 1,80 & 3,32 \\
\hline TR21 & 15 & 2,34 & 15,39 & 11,75 & 70,37 & 0,28 & 2,20 \\
\hline TRC1 & 16 & 2,04 & 10,85 & 12,26 & 75,19 & 0,98 & 0,73 \\
\hline TR22 & 17 & 2,01 & 45,02 & 17,50 & 29,16 & 6,58 & 1,75 \\
\hline TR62 & 18 & 1,84 & 11,21 & 28,13 & 49,45 & 6,33 & 4,87 \\
\hline
\end{tabular}

- The provinces classified within NUTS2 regions are determined as TR10 (İstanbul), TR21 (Tekirdağ, Edirne, Kırklareli), TR22 (Balıkesir, Çanakkale), TR31 (İzmir), TR32 (Aydın, Denizli, Muğla), TR33 (Manisa, Afyon, Kütahya, Uşak), TR41(Bursa, Eskişehir, Bilecik), TR42 (Kocaeli, Sakarya, Düzce, Bolu, Yalova), TR51 (Ankara), TR52 (Konya, Karaman), TR61 (Antalya, Isparta, Burdur), TR62 (Adana, Mersin), TR63 (Hatay, Kahramanmaraş, Osmaniye), TR71 (Kırıkkale, Aksaray, Niğde, Nevşehir, Kırşehir), TR72 (Kayseri, Sivas, Yozgat), TR81 (Zonguldak, Karabük, Bartın), TR82 (Kastamonu, Cankırı, Sinop), TR83 (Samsun, Tokat, Corum, Amasya), TR90 (Trabzon, Ordu, Giresun, Rize, Artvin, Gümüşhane), TRA1 (Erzurum, Erzincan, Bayburt), TRA2 (Ağrı, Kars, lğdır, Ardahan), TRB1 (Malatya, Elazı̆̆, Bingöl, Tunceli), TRB2 (Van, Muş, Bitlis, Hakkari), TRC1 (Gaziantep, Adıyaman, Kilis), TRC2 (Şanlıurfa, Diyarbakır), TRC3 (Mardin, Batman, Şırnak, Siirt). 


\begin{tabular}{|c|c|c|c|c|c|c|c|}
\hline NUTS2 Code & GDP Rank & Regional GDP & Energy & Services & Manufacturing & Mining & Agriculture \\
\hline TR71 & 19 & 1,37 & 18,98 & 17,73 & 53,00 & 5,38 & 4,91 \\
\hline TRB1 & 20 & 1,32 & 24,97 & 24,75 & 36,79 & 11,89 & 1,60 \\
\hline TRC3 & 21 & 1,24 & 28,54 & 33,81 & 30,03 & 4,66 & 2,96 \\
\hline TRB2 & 22 & 1,07 & 31,48 & 34,17 & 28,44 & 4,17 & 1,74 \\
\hline TR81 & 23 & 0,94 & 21,02 & 39,78 & 26,18 & 12,67 & 0,35 \\
\hline TRA1 & 24 & 0,89 & 41,37 & 19,53 & 24,70 & 13,11 & 1,29 \\
\hline TR82 & 25 & 0,72 & 20,54 & 21,14 & 51,54 & 4,31 & 2,48 \\
\hline TRA2 & 26 & 0,64 & 32,45 & 43,31 & 21,02 & 2,05 & 1,18 \\
\hline $\begin{array}{c}\text { Average } \\
\text { Inv. (of total } \\
\text { inv. \%) }\end{array}$ & & & 0,24 & 0,29 & 0,41 & 0,05 & 0,02 \\
\hline
\end{tabular}

Note: Regional calculations are based on the average of the years 2004-2018. Regional GDP is the rate of GDP to total GDP.

The analysis had four parts. It created four main estimation models to examine the impact of investment incentives on regional economic growth and regional economic sectors. Model 1 analysed the impacts of the sub-components of total regional investment incentives on regional economic growth. Model 2 analysed the impact of regional investment incentives to agricultural sector on regional agricultural sector. Model 3 analysed the impact of regional investment incentives to service sector on regional service sector. Finally, Model 4 analysed the impact of regional investment incentives to industrial sector on regional industrial sector. The models were based on studies of Reside (2007), Gerni et al. (2015), and Çelik (2017). They are summarized in the following equations:

Model 1: $\quad g d p_{i t}=\beta_{0}+\beta_{1}$ open $_{i t}+\beta_{2}$ pop $_{i t}+\beta_{3}$ totalinv $_{i t}+e_{i t}$

Model 2: agrigdp $i t=\beta_{0}+\beta_{1}$ open $_{i t}+\beta_{2}$ pop $_{i t}+\beta_{3}$ agrinv $_{i t}+e_{i t}$

Model 3: servgdp $p_{i t}=\beta_{0}+\beta_{1}$ open $_{i t}+\beta_{2}$ pop $_{i t}+\beta_{3}$ servinv $_{i t}+e_{i t}$

Model 4: indgdp it $=\beta_{0}+\beta_{1}$ open $_{i t}+\beta_{2}$ pop $_{i t}+\beta_{3}$ manuinv $_{i t}+e_{i t}$

In the equations, i indicates cross sectional units (26 Development Regions), and $t$ indicates time dimension (2004-2018). In models, gdp indicates regional real per capita GDP level, agrigdp indicates the share of agricultural sector in regional GDP, servgdp indicates the share of service sector in GDP, indgdp indicates the share of industrial sector in regional GDP. In addition, open and pop variables included in models as control variables represents trade openness and population level in regions. In models, totalinv (included as an independent variable) represents the share of regional total investment 
incentives in regional GDP. agrinv represents the share of investment incentives to agricultural sector in total investment incentives, servinv represents the share of investment incentives to service sector in total investment incentives, manuinv represents the share of investment incentives to manufacturing sector in total investment incentives. Table A1 in the Appendix presents the summary statistics of the variables used in models.

\subsection{Estimation Results}

This study uses panel data analysis to examine the impact of regional investment incentives in Turkey on regional economic growth and regional economic sectors. The analysis consists of two main steps. The cross-sectional dependencies of the series in panel data analysis are essential in terms of efficiency and consistency in estimating the models. Therefore, first, cross-sectional dependencies of the variables used in models were determined. According to the test results, stationary levels of the series were determined using an appropriate unit root test. Various tests were performed to make assumptions of the estimation model. Linear regression models in panel data analysis rely on the key assumption of the absence of cross-sectional dependence, autocorrelation, and heteroscedasticity. Thus, the Panel Corrected Standard Error (PCSE) method, frequently referred to as "Beck and Katz estimator" in the literature, was used in model estimations to make our analysis rigorous and robust (Becks and Katz, 1995: 634-635). Since the relation of each section with each other and the shocks to the units affect other units (regions) in the panel data analysis, failure to consider this relationship in the analysis prevents the results from being efficient and consistent. For this purpose, firstly, cross-sectional dependencies of the series were determined in this study. Since the cross-sectional dimension $(N=26)$ is larger than the time dimension ( $T=$ 15), Bias-Adjusted Cross-sectional Dependence Lagrange Multiplier test (CDLMadj test) developed by Ullah and Yamagata (2008) was used. Table 2 summarizes the cross-sectional dependence test results of the variables. This result indicates that the shocks occurring in the units affect other units of the panel. As the crosssectional dependence was determined by the test, stationary levels of the series were determined by Pesaran (2007) Dickey-Fuller Test (CADF) taking the crosssection dependence into account. The results of CADF test with the null hypothesis as "series is not stationary" are indicated in Table 2. According to the results, all variables become stationary in their first differences. Therefore, it was determined that variables had no unit roots. 
Table 2: The results of Unit Root Test and Cross Section Dependence Test

\begin{tabular}{|c|c|c|c|c|c|c|c|}
\hline \multirow{2}{*}{ Voriable } & \multirow{2}{*}{ Constont } & \multirow{2}{*}{ Trend } & \multirow{2}{*}{ Voriable } & \multirow{2}{*}{ Constont } & \multirow{2}{*}{ Trend } & \multicolumn{2}{|c|}{$C D L M_{o d j}$} \\
\hline & & & & & & Stotistic & $P$-value \\
\hline$g d p$ & -1.426 & -1.474 & $\Delta g d p$ & $-2.370^{* * *}$ & $-2.860^{\circ+* * *}$ & 69.66821 & 0.000 \\
\hline ogrigdp & -1.546 & -2.161 & $\Delta$ ogrigdp & -2.611 & $-2.629^{* *}$ & 53.4689 & 0.000 \\
\hline servgdp & -4.341 & -1.569 & $\Delta$ servgdp & $-2.000^{* *}$ & $-3.648^{* * *}$ & 29.5853 & 0.000 \\
\hline indgdp & -1.263 & -1.149 & $\Delta$ indgdp & $-2.918^{* \ldots *}$ & $-3.379^{*+*}$ & 46.1284 & 0.000 \\
\hline open & -1.755 & $-3.969^{* * *}$ & Dopen & $-2.032^{* *}$ & $-3.969^{\ldots *}$ & 28.7488 & 0.000 \\
\hline pop & -1.513 & -1.320 & $\Delta p o p$ & $-2.389^{\cdots * *}$ & $-2.861^{*+*}$ & 127.3618 & 0.000 \\
\hline totalinv & $-2.454^{*+* x}$ & -2.494 & $\Delta$ totolinv & $-2.682^{* * *}$ & $-2.532^{* * *}$ & 22.3793 & 0.000 \\
\hline agrinv & -2.087 & -2.265 & Dagrinv & $-2.971^{\cdots *}$ & $-3.046^{m+n}$ & 11.2672 & 0.000 \\
\hline servinv & $-2.298^{* x}$ & -2.578 & $\Delta$ servinv & $-3.132^{* * x}$ & $-2.907^{*+*+}$ & 7.7318 & 0.000 \\
\hline manuinv & -2.390 & -2.726 & $\begin{array}{l}\Delta \text { manu- } \\
\text { inv }\end{array}$ & $-3.131^{\ldots *}$ & $-3.086^{\cdots *}$ & 5.9303 & 0.000 \\
\hline
\end{tabular}

Note: ${ }^{* * *},{ }^{* *},{ }^{*}$ represent $1 \%, 5 \%$ and 10\% significant level respectively

In panel data analysis, it is important to determine whether the pooled, random and fixed effect models are appropriate in the estimated models. Firstly, Hausman Test (1978) was used to determine whether the models have fixed or random effect or not. Hausman test results are indicated in the same table as the related model results. Autocorrelation, heteroscedasticity, and cross-sectional dependence problems in the related models were determined according to fixed or random effects. Hausman Test results indicate that all three models have fixed effects. Therefore, the assumption tests were performed based on the fixed effects model. Whether the heteroscedasticity in all models was determined by Lagrange Multiplier (LM) Test and Modified Wald Test, the presence of autocorrelation in the models was determined by Wooldridge Autocorrelation Test, and Friedman Q Test determined the cross-sectional dependence of the models. The result of the assumption tests summarized in Table 3 concluded that all models have autocorrelation, heteroscedasticity, and cross-sectional dependence. For the coefficients obtained from the varying estimated regression models to be consistent and effective in panel data analysis, robust estimators to these problems should be used. For that reason, Panel Corrected Standard Error (PCSE) method that eliminates the heteroscedasticity, autocorrelation, and cross-sectional dependence and makes the models robust is preferred in this study. 
Table 3: The Result of Robust Panel Regression Models (PCSE)

\begin{tabular}{|c|c|c|c|c|}
\hline $\begin{array}{l}\text { Voriables } \\
\text { Dependent } \\
\text { Voriable }\end{array}$ & $\begin{array}{l}\text { Model } 1 \\
\text { (gdp) }\end{array}$ & $\begin{array}{l}\text { Model } 2 \\
\text { (agrigdp) }\end{array}$ & $\begin{array}{l}\text { Model } 3 \\
\text { (servgdp) }\end{array}$ & $\begin{array}{l}\text { Model } 4 \\
\text { (indgdp) }\end{array}$ \\
\hline c & $\begin{array}{l}10.514 \text { "." } \\
(0.000)\end{array}$ & $\begin{array}{l}-1.8717^{\cdots *} \\
(0.052)\end{array}$ & $\begin{array}{c}0.8292 \ldots \\
(0.026)\end{array}$ & $\begin{array}{c}-0.70621^{\prime *} \\
(0.021)\end{array}$ \\
\hline open & $\begin{array}{l}0.08677^{\cdots} \\
(0.024)\end{array}$ & $\begin{array}{l}-0.2121 * \cdots \\
(0.032)\end{array}$ & $\begin{array}{l}0.5724 \cdots \\
(0.380)\end{array}$ & $\begin{array}{l}0.2813^{\prime * \prime} \\
(0.009)\end{array}$ \\
\hline pop & $\begin{array}{l}0.940 \cdots \\
(0.083)\end{array}$ & $\begin{array}{l}-0.032 " * \\
(0.054)\end{array}$ & $\begin{array}{l}0.026 \cdots \\
(0.017)\end{array}$ & $\begin{array}{l}0.002^{\cdots} \\
(0.000)\end{array}$ \\
\hline totalinv & $\begin{array}{l}0.3051 \\
(0.613)\end{array}$ & & & \\
\hline ogrinv & & $\begin{array}{l}3.517^{\prime \prime \prime} \\
(0.833)\end{array}$ & & \\
\hline servinv & & & $\begin{array}{l}0.3715^{\prime \prime \prime} \\
(0.1133)\end{array}$ & \\
\hline manuinv & & & & $\begin{array}{l}0.777^{\prime \prime \prime} \\
(0.190)\end{array}$ \\
\hline$R^{2}$ & 0.3776 & 0.8198 & 0.3239 & 0.6289 \\
\hline $\begin{array}{l}\text { Wald Chi2 } \\
\text { (p-value) }\end{array}$ & $\begin{array}{c}352.42 \\
(0.0000)\end{array}$ & $\begin{array}{l}2199.52 \\
(0.0000)\end{array}$ & $\begin{array}{l}1293.20 \\
(0.0000)\end{array}$ & $\begin{array}{l}1170.35 \\
(0.0000)\end{array}$ \\
\hline Housman Test & $46.90(0.000)$ & $12.77(0.005)$ & $20.41(0.000)$ & $44.86(0.000)$ \\
\hline $\begin{array}{l}\text { Friedman Q } \\
\text { Test }\end{array}$ & $0.557(0.000)$ & $0.446(0.000)$ & $0.438(0.000)$ & $0.479(0.000)$ \\
\hline LM Test & 207.10 (0.000) & $\begin{array}{l}2313.68 \\
(0.000)\end{array}$ & $\begin{array}{c}1635.63 \\
(0.000)\end{array}$ & $1283.16(0.000)$ \\
\hline Wold Test & $\begin{array}{c}3226.23 \\
(0.000)\end{array}$ & 237.74 (0.000) & $228.25(0.000)$ & 2122.19 (0.000) \\
\hline $\begin{array}{l}\text { Wooldridge } \\
\text { Test }\end{array}$ & $\begin{array}{l}434.287 \\
(0.000) \\
\end{array}$ & $28.435(0.000)$ & 70.711 (0.000) & 92.299 (0.000) \\
\hline Obs. & 390 & 390 & 390 & 390 \\
\hline
\end{tabular}

Note: Panel corrected standard errors in parentheses. ***, **, * represent $1 \%, 5 \%$ and $10 \%$ significance levels, respectively. 
Table 3 indicates the results of the models estimated to reveal the impact of regional investment incentives in Turkey on regional economic growth and sub-sectors. In general, the results of this study are consistent with the existing literature. According to fixed effect model corrected with the panel PCSE method, there is a significant and positive relationship between total regional investment incentives and economic growth. In other words, as total regional investment incentives increases, economic growth increases. Although total investment incentives have low rates, especially in Turkey with high regional disparities, it can be noted that they are regionally effective. Model 2 is estimated to analyse the impact of agricultural investment incentives on the agricultural sector. Results show that agricultural investment incentives on regional agriculture in GDP are statistically significant and positive. These results indicate that the agricultural investment incentives increase regional agriculture development.

According to the estimation results, the impact of manufacturing investment incentives on the industrial sector in Turkey was statistically significant and positive at $1 \%$ significance level. The estimates also indicate that $1 \%$ unit change in the manufacturing investment incentives leads to $0.77 \%$ change in industrial sector, positively. This result confirms that manufacturing investment incentives is a significant factor in attracting regional development. In Model 3, we examined the impact of investment incentives on the services sector. According to the estimation results, the impact of investment incentives on the service sector in Turkey was statistically significant and positive at $1 \%$ significance level. However, the coefficients of total investment incentives, manufacturing investment incentives, and service sector investment incentives are very low in regional development compared to the agricultural sector. According to the values of the coefficients of the models, we determined that the most effective sector is the agricultural sector among the investment incentives. These estimates indicate that agricultural sector investment incentives are more effective than other sectors in regional development in Turkey. Although the contribution of agricultural sector to GDP in Turkey is relatively low, this impact needs to be investigated in future studies both based on causality and considering the short and long-term effects. From this point of view, these results reveal that the impact in other sectors also needs to be examined again in further studies by considering the short and long-term effects. On the other hand, as stated in the study of Sağbaş et al. (2016), investment incentives can also cause inefficiency by causing unnecessary production in the areas and 
regions that are encouraged with investment incentives. Finally, the results of Çelik (2017) based on the efficiency of manufacturing sector investments show that incentive policies are inefficient at macro level and that the incentives have a positive effect on investment decisions in their regions because of the crucial spatial effects of regional investments in Turkey. Study also presents impressive results regarding trade openness levels included as control variables in the models. Trade openness has a statistically significant and positive impact on total GDP, industrial sector, and services sector as expected in the literature. However, it was determined that the impact of trade openness on agricultural sectors is statistically significant and negative. The negative impact of trade openness on the agricultural sector is regarded as understandable when Turkey's agricultural import in total import is analysed by years. Turkey's import of agricultural products was increasingly at high rates within the total import rate by the years.

\section{CONCLUSIONS}

Investment incentives are one of the most important policies used by governments to achieve economic development and growth. Especially in developing countries, realizing production by supporting the agriculture, industrial and service sectors is among the main objectives. From a historical perspective, governments' intervention in the economic sphere is criticised by many economic views. Particularly classical economists evaluate the economic intervention of governments as a source of unproductivity and inefficiency for whatever reason. However, the economic problems experienced after the Great Depression of 1929 and the failure of classical economists to find complete solutions for many problems so far brought the economic intervention of governments into question. With the emergence of the Keynesian view of economics, many countries have realized their objectives such as growth and development by increasing the economic role of their governments. In addition, along with the problems based on market failure, the neo-classical economic view also anticipated the intervention of governments in economy in a limited way. There are two main problems in development and growth of developing countries. The first is the inability to benefit from the technologies of foreign investments and companies coming to the country in the long term. The main problem here is that the technology and innovation skills offered by foreign 
capital cannot be used in the development of the country. The second is the inability to prevent both efficient allocation of resources and clustering of domestic production in certain regions, even if growth is realized. In this sense, when considered in terms of economic sectors, for example, when the industrial sector is concentrated in a specific region, other regions' resources and other advantages cannot be fully utilized. In this respect, it is necessary to develop regional growth policies to eliminate regional differences. Various studies on this problem stand out in theoretical and empirical literature. In Turkey, regional disparities affect economic growth and regional development negatively. For instance, approximately 60\% of the total production in Turkey is realized in the Marmara Region with an intense industrial sector. In this sense, main policies such as investment incentives have been implemented in Turkey for years to realize regional production and eliminate regional disparities. One of the main objectives of this study was to reveal the effectiveness of these regional investment incentives in terms of regional development.

The main objective of this empirical study, which was designed with the motivation mentioned above, was to investigate the impact of investment incentives on regional economic growth in 26 development regions of Turkey for the period of 2014-2018 using panel data analysis. With this aim, four main estimation models were created to analyse the impacts of investment incentives on regional economic growth and economic sectors. First, the impact of total investment incentives on regional economic growth was analysed. In addition, the impact of investment incentives to agricultural sector on regional agricultural sector, the impact of investment incentives to services sector on regional services sector, and the impact of investment incentives to industrial sector on regional industrial sector were estimated as separate models. The stationary and cross-sectional dependence of the series used in models were initially investigated in the analysis part. Accordingly, the estimator of models was determined. Cross-sectional dependence, heteroscedasticity, and autocorrelation problems belonging to estimation models were also determined to make estimations robust. Since the mentioned problems were determined in all models, Panel Corrected Standard Error Method (PCSE) corrected the estimations by eliminating heteroscedasticity, autocorrelation, and crosssectional dependence in the estimated models. 
The findings of this study indicated that the impact of total regional investment incentives on regional economic growth was statistically significant and positive at $1 \%$ significance level. This result indicated that regional investment incentives in Turkey were effectively used in regional development policies. We can state that especially efficiency of the regions that contribute low amounts to the GDP level increased in this way. However, the lower coefficients of the variables indicated that regional investment incentives should be increased to reduce the regional disparities and foster regional economic growth. The results of this study are compatible with the results of the studies by Loh (1993), Goss and Philips (1999), Yavan (2011), Taşdoğan (2013), Reside (2007), Gerni et al. (2015), Sevinç et al. (2016), Sağbaş et al. (2016), Değer and Recepoğlu (2017), and Gömleksiz et al. (2017). We also determined that the impact of the industrial sector's investment incentives had a significantly positive effect on the industrial sector and the impact of the service sector investment incentives had a significantly positive effect on the service sector in Turkey.

These results, which are compatible with the study by Çelik (2017), indicate that exporter companies in Turkey's manufacturing sector use the government's investment incentives effectively. Likewise, estimates of the agricultural sector investment incentives exhibit a positive and significant effect on the regional agriculture sector. This result suggested that agricultural sector investment incentives were more effective than other sectors in regional development. Considering the factors such as the modernization failure and low factor productivity in agricultural sector, and increasing agricultural import in Turkey, we can say that the positive effect of incentives for agricultural sector will make significant contributions to regional development in the long term. Moreover, we found that trade openness level included in the models as a control variable had a positive impact on economic growth, service sector, and industrial sector as expected in the literature. However, the impact of trade openness on the agricultural sector is negative and significant. We think that the negative impact of trade openness on agricultural sector is due to the gradual increase in the share of agricultural product import of Turkey in total import by years. In addition, similar results were obtained in many studies investigating agricultural sector at the regional level in Turkey. In general, the regional share of agricultural sector in Turkey is related to similar results with increasing trend regional variables such as GDP, trade openness, tax revenues, and population. 
These results have important policy implications. First, our results are important in terms of the efficiency of investment incentives and long-term policies. Moreover, they suggest that both efficiency and amounts of regional investment incentives should be increased to reduce the regional disparities and foster regional economic growth. Although the contribution of the agricultural sector to GDP in Turkey is relatively low, this impact needs to be investigated in future studies both on the basis of causality and considering the short and long-term effects. Similarly, the impact of investment incentives on industrial sector reveals that this impact should be examined by considering both time and regional data. In addition, the impact of trade openness level included in the models as a control variable on the agricultural sector yielded a result contrary to the studies in the literature. In this respect, our study revealed that the size and direction of this negative impact should be investigated in future research. 


\section{REFERENCES}

Akan, Yusuf and ibrahim Arslan (2008), Türkiye'de Sektörel Yatırım Teşvik Belgeleri ile İstihdam Analizi: Doğu Anadolu Bölgesi Üzerine Bir Uygulama (1980-2006)", Çalışma ve Toplum, 1, pp. 107-119.

Ay, Hakkı M. (2005), "Yatırım Teşviklerinin Sabit Sermaye Yatııımları Üzerindeki Etkisi", Selçuk Üniversitesi Karaman İktisadi ve İdari Bilimler Dergisi, 2(5), pp. 176-184.

Ayele, Seife (2006), "The Industry and Location Impacts of Investment Incentives on SMEs Start-Up in Ethiopia", Journal of International Development, 18, pp. 1-13.

Bartik, Timothy J. (2005), "Solving the Problems of Economic Development Incentives", Growth and Change, 36(2), pp. 139-166.

Baykul, Ayşegül; Selen Işık Maden and Demet Kutgi (2019), “Bölgesel Kalkınma Politikası Aracı Olarak Kamu Yatırımları ve Teşvikler: Türkiye'de Düzey 2 Bölgeleri Üzerine Bir Etkinlik Analizi", Avrasya Uluslararası Araştırma Dergisi, 7(16), pp. 652-669.

Beck, Nathaniel and Jonathan N. Katz (1995), "What to do (and not to do) with Time-Series Cross-Section Data", The American Political Science Review, 89(3), pp. 634-647.

Bondonio, Daniele and Robert T. Greenbaum (2006), "Do Business Investment Incentives Promote Employment in Declining Areas? Evidence from EU Objective-2 Regions", European Urban and Regional Studies, 13(3), pp. 225-244.

Cambini, Carlo and Laura Rondi (2009), "Incentive regulation and investment: evidence from European energy utilities", J Regul Econ, 38, pp. 1-26.

Çelik, Necmettin (2017), “Teşvik Politikalarının Etkinliğinin Mekansal Perspektiften Değerlendirilmesi", Ege Akademik Bakış, 17(1), pp. 1-12.

Chaudhuri, Ray (2001), An Introduction to Development and Regional Planning, Orient Longman Limited, India.

Cleeve, Emmanuel (2008), "How Effective Are Fiscal Incentives to Attract FDI to Sub-Saharan Africa?", The Journal of Developing Areas, 42(1), pp. 135-153.

Değer, Mustafa Kemal and Mürşit Receopoğlu (2017), "Yerel Ekonomik Büyümede Devletin Rolü: Kamu Yatırım Harcamaları mı Yoksa Yatııım Teşvikleri mi?", ÇYYD, 27(1), pp. 1-22.

Demirtaş, Gökhan and Ebuzer Aksel (2018), "Bölgesel Kalkınmada Kamunun Rolü: Türkiye Üzerine Ampirik Bir Analiz", Sosyoekonomi, 26(37), pp. 171-184.

Ekinci, Filiz, Gözde Kocaand Şemsettin Yüce(2019), “Yatırımlarda Vergisel Teşvikler: Güneydoğu Anadoluı Bölgesi Değerlendirmesi Şırnak ili Örneği", Sakarya İktisat Dergisi, 8(4), pp. 311-330. 
Gabe, Todd M. and David S. Kraybill (2002), "The Effect of State Economic Development Incentives on Employment Growth of Establishments", Journal of Regional Science, 42(4), pp. 703-730.

Gerni, Cevat; Selahattin Sarı, Haktan Sevinç and Ömer Selçuk Emsen (2015), "Bölgesel Dengesizliklerin Giderilmesinde Yatırım Teşviklerinin Rolü ve Başarı Kriteri Olarak Yakınsama Analizleri: Türkiye Örneği", International Conference on Eurasian Economies, Istanbul: Eurasian Economists Association, 9-11 September.

Gömleksiz, Mustafa, Ahmet Şahbaz and Birol Mercan (2017), "Regional Economic Convergence in Turkey: Does The Government Really Matter For?", Economies, 5(27), pp. 1-16.

Goss, Ernest and Joseph M. Philips (1999), “Do Business Tax Incentives Contribute to A Divergence in Economic Growth?", Economic Development Quarterly, 13(3), pp. 217228.

Gülmez, Mustafa and Illkay Noyan Yalman (2010), "Yatırım Teşviklerinin Bölgesel Kalkınmaya Etkileri: Sivas İli Örneği", Atatürk Üniversitesi İktisadi ve İdari Bilimler Dergisi, 24(2), pp. 235-257.

Hausman, Jerry A. (1978), "Specification Tests in Econometrics", Econometrica, 46(6), pp. 1251-1271.

Hazman, Gülsüm Gürler (2010), "Türkiye'de Mali Nitelikteki Teşviklerin Doğrudan Yabancı Sermaye Üzerindeki Etkisi: Toda-Yamamato Nedensellik Analizi Çerçevesinde Değerlendirme", Maliye Dergisi, 158, pp. 262-277.

Hazman, Gülsüm Gürlerand PınarBengi Kaya(2018), "Bölgesel Teşvik Uygulamaları ile ihnracat İlişkisinin Afyonkarahisar Ilii Örneğinde Regresyon Analizi ile Değerlendirilmesi", Avrasya Sosyal ve Ekonomi Araştırmaları Dergisi, 5, pp. 41-60.

Karaalp, Hacer Simay (2014), "The Effect of Public Investment and Firm-Based Investment Incentives on Employment: A Panel Data Analysis for Turkey", Journal of Economic and Social Development, 1(1), pp. 74-85.

Karaş, Göksel and Ebru Karaş (2019), "Mali Teşvik Sisteminde Yer Alan Amaç ve Araçlara Iliş̧kin Genel Bir Değerlendirme", Türkiye'de Mali Teşvik Sistemi ve Uygulamaları İçinde, Mustafa Taytak, Mahmut Ünsal Şaşmaz (Eds.), Ekin Yayın, Bursa.

Koç, Özgür Emre and Taha Bahadır Saraç (2020), "Türkiye'de Sanayi Kesimine Yönelik Uygulanan Vergi Teşviklerinin Sanayi Üretimi Üzerindeki Etkisi", Iktisadi İdari ve Siyasal Araştırmalar Dergisi, 5(13), pp. 331-346. 
Loh, Eng Seng (1993), "The Effects of Jobs-Targeted Development Incentive Programs", Growth and Change, 24, pp. 365-383.

Mohl, Philipp and Tabias Hagen (2010), “Do EU Structural Funds Promote Regional Growth? New Evidence from Various Panel Data Approaches", Regional Science and Urban Economics, 40, pp. 353-365.

OECD (2001), "Competition Policy in Subsidies and State Aid", Policy Roudtables, DAFFE/ CLP(2001)24.

Öz, Ersan and Selçuk Buyrukoğlu (2017), “Türkiye'de Uygulanan Yatırım Teşvik Politikalarının Makroekonomik Değişkenler Üzerindeki Etkisinin Ampirik Analizi", Pamukkale Üniversitesi Sosyal Bilimler Enstitüsü Dergisi, 27, pp. 322-336.

Pesaran, M. Hashem (2007), "A Simple Panel Unit Root Test in the Presence of CrossSection Dependence", Journal of Applied Econometrics, 2(2), pp. 265-312.

Prillaman, Soledad Artiz and Kenneth J. Meier (2014), "Taxes, Incentives, and Economic Growth: Assessing The Impact of Pro-Business Taxes on U.S. State Economies", The Journal of Politics, 76(2), pp. 364-379.

Recepoğlu, Mürşit and Mustafa Kemal Değer (2016), “Türkiye'de Bölgesel Yatırım Teşviklerinin Bölgesel Ekonomik Büyüme Üzerine Etkisi: Düzey 2 Bölgeleri Üzerine Panel Veri Analizleri (2004-2011)". Kastamonu Üniversitesi İktisadi ve İdari Bilimler Fakültesi Dergisi, 14, pp.6-21.

Reside, Renato E. (2007), "Can Fiscal Incentives Stimulate Regional Investment in The Philippines?", UPSE Discussion Paper, No. 0705.

Sağbaş, İsa (2002), "Türkiye'de Kamu Harcamalarının Yakınsama Üzerindeki Etkisi", Afyon Kocatepe Üniversitesi iliBF Dergisi, 4, pp.137-148.

Sağbaş, İsa, Saffet Erdoğan and Hüseyin Şen (2016), “Türkiye'de Sektör Bazılı Bölgesel Teşvik Sistemi ve Ekonomik Etkileri", 26. International Public Finance Conference, Şanlıurfa: Harran University, 2-5 May.

Saygll, Hülya (2020), "Do Investment Incentives Promote Regional Growth and Income Convergence in Turkey?", Central Bank of the Republic of Turkey Working Paper, 20/13.

Schalk, Hans Joachim and Gerhard Untiedt (2000), "Regional Investment Incentives in Germany: Impacts on Factor Demand and Growth", Ann Reg Sci, 34, pp. 173-195.

Selen, Ufuk (2011), Maliye Politikası Aracı Olarak Teşvik Uygulamaları, Ekin Yayın, Bursa. 
Sevinç, Haktan; Ö. Selçuk Emsen and Eda Bozkurt (2016), "Yatırım Teşvik Politikalarının Bölgesel Belirleyicilerine Yönelik Bir Analiz: Türkiye Örneği". Çankırı Karatekin University Journal of The Faculty of Economics and Administrative Sciences, 6(1), pp. 525-556.

Şahin, Mehmetand Özge Uysal (2011), “Bölgesel Kalkınma Çerçevesinde Yatırım Teşviklerinin Shift-Share Analizi", Maliye Dergisi, 160, pp. 111-138.

Şaşmaz, Mahmut Ünsal and Öznur Özel (2019), "Tarım Sektörüne Sağlanan Mali Teşviklerin Tarım Sektörü Gelişimi Üzerindeki Etkisi: Türkiye Örneği”, Dumlupınar Üniversitesi Sosyal Bilimler Dergisi, 61, pp. 50-65.

Selim, Sibel, O. Murat Koçtürk and Pınar Eryiğit (2014), "Türkiye'de Yatırım Teşvikleri ve Sabit Yatırımların İstihdam Üzerine Etkisi: Panel Veri Analizi", Ege Akademik Bakış, 14(4), pp. 661-673.

Tansel, Aysit and Nil Demet Güngör (1999), "Economic Growth and Convergence: An Application to The Provinces of Turkey, 1975-1995", ERC Working Paper No.98/9, Economic Research Center, Middle East Technical University.

Taşdoğan, Celal (2013), "Yeni Teşvik Programı: Stokastik Sınır Analizi lle Bir Değerlendirme", Ekonomik Yaklaşım, 24(89), pp. 1-23.

Tung, Samuel and Stella Cho (2001), "Determinants of Regional Investment Decisions In China: An Econometric Model of Tax Incentive Policy", Review of Quantitative Finance and Accounting, 17, pp. 167-185.

Yanıkkaya, Halit and Hasan Karaboga (2017), "The Effectiveness of Investment Incentives in the Turkish Manufacturing Industry", Prague Economic Papers, 26(6), pp. 744-760.

Yavan, Nuri (2011), "Teşviklerin Bölgesel Ekonomik Büyüme Üzerindeki Etkisi: Ampirik Bir Analiz", Ekonomik Yaklaşım, 22(81), pp. 65-104.

Yavuz, Ali (2010), “Bir Maliye Politikası Aracı Olarak Yatırım Teşviklerinin Rekabet Koşulları Altında Özel Kesim Yatırımları ve İstihdam Üzerine Etkisi: Ekonometrik Bir Analiz", Süleyman Demirel Üniversitesi İktisadi ve İdari Bilimler Fakültesi Dergisi, 15(1), pp. 83-101.

Yıldırım, Jülide, Nadir Öcal, Süheyla Özyıldııım (2009), "Income Inequality and Economic Convergence in Turkey: A Spatial Effect Analysis", International Regional Science Review, 32(2), pp. 221-254.

Zeren, Fatma and Veli Yılancı (2011), "Türkiye'de Bölgeler Arası Gelir Yakınsaması: Rassal Katsayılı Panel Veri Analizi Uygulaması,' Business and Economics Research Journal, 2(1), pp. 143-151. 


\section{APPENDIX}

Table A1: Summary Statistics

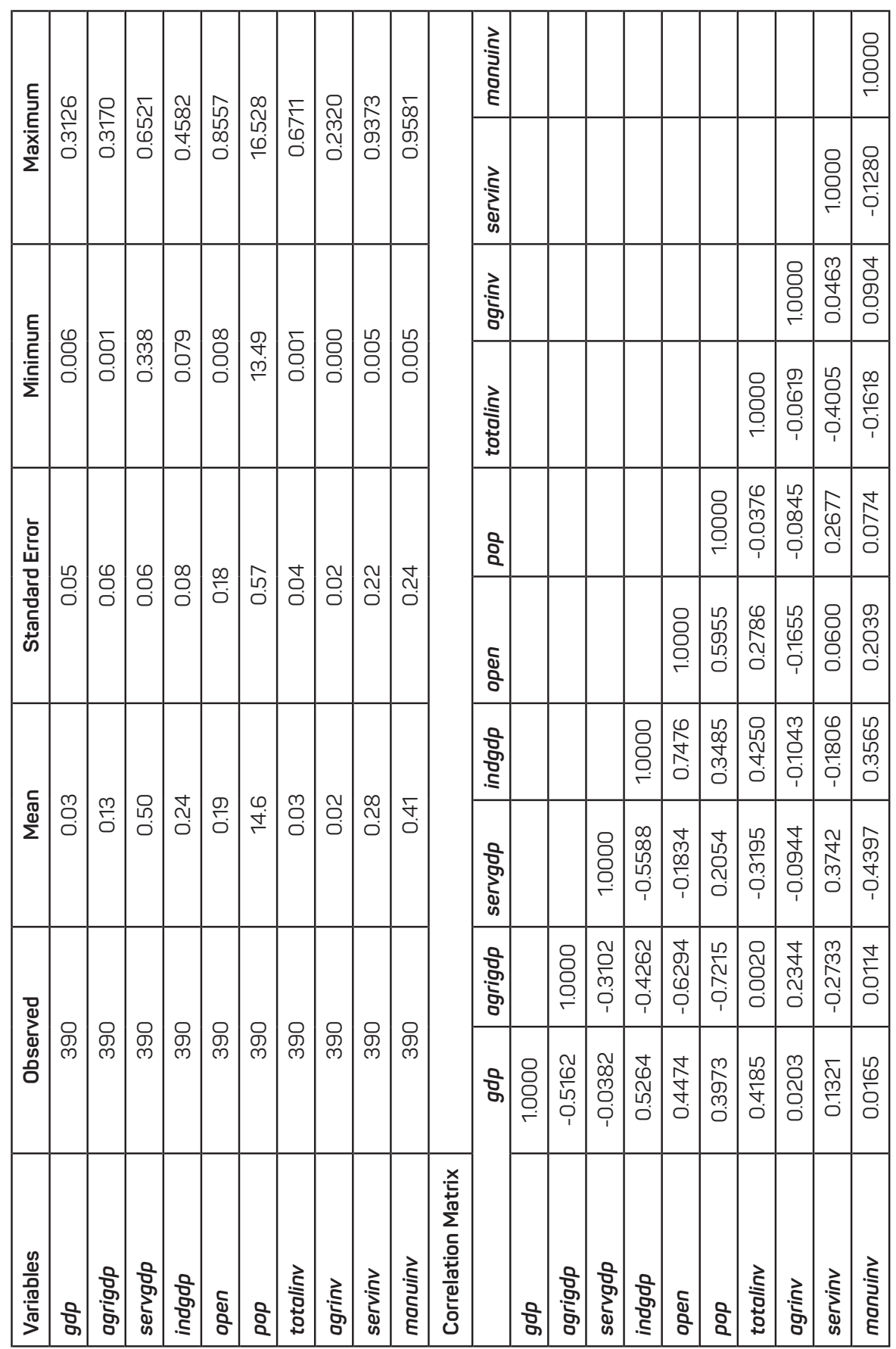




\section{GENIŞLETILMIŞ ÖZET}

Yatııım teşvikleri, hükümetlerin ekonomik kalkınma ve büyümenin gerçekleştirilmesi için kullandıkları en önemli politikalardan biridir. Özellikle gelişmekte olan ülkelerde tarım, sanayi ve hizmet sektörlerinin birbirlerini desteklemesi yoluyla üretimin gerçekleştirilmesi temel hedefler arasındadır. Tarihsel açıdan değerlendirildiğinde devletin ekonomik alana müdahalesi, birçok iktisadi görüş tarafından olumlu karşılanmamaktadır. Özellikle klasik iktisatçılar devletin hangi nedenle olursa olsun ekonomiye müdahalesini, verimsizlik ve etkinsizlik kaynağı olarak görmektedirler. Fakat 1929 Büyük Buhranı'ndan sonra yaşanan ekonomik olumsuzluklar ve günümüze kadar gelen birçok soruna Klasik iktisatçıların tam anlamıyla çözüm bulamamaları, devletin ekonomik müdahalesini tekrar gündeme getirmiştir. Keynesyen iktisat görüşünün doğmasıyla birlikte birçok ülke büyüme ve kalkınma gibi hedeflerini, devletin ekonomik rolünü artırarak gerçekleştirmiştir. Bunun yanında piyasa başarısızlığı temelinde yaşanan sorunlarla birlikte Neo-klasik iktisat görüşü de devletin ekonomiye müdahalesini sınırlı bir şekilde öngörmüştür.

Gelişmekte olan ülkelerin büyüme ve kalkınmalarında temel olarak iki husus sorun teşkil etmektedir. Bunlardan birincisi ülkeye gelen yabancı yatırımların ve firmaların teknolojilerinden uzun vadede faydalanamamaktır. Burada temel sorun yabancı sermayenin sunmuş olduğu teknoloji ve inovasyon becerilerinin ülkenin gelişiminde yeterince kullanılamamasıdır. Ikinci husus ise büyüme gerçekleşse bile hem kaynakların etkin tahsisinin sağlanamaması hem de üretimin belli bölgelerde kümelenmesinin engellenememesidir. Bu anlamda iktisadi sektörler açısından düşünüldüğünde, örneğin sanayi sektörü belli bir bölgede yoğunlaştığında diğer bölgelerin kaynaklarından ve diğer avantajlarından tam olarak faydalanılamamaktadır. Bu açıdan bölgesel farkılıkların giderilmesi için bölgesel düzeyde büyüme politikaları geliştirilmesi gerekmektedir. Hem teorik açıdan hem de ampirik literatür açısından bu sorun ile ilgili çok sayıda çalışma göze çarpmaktadır. Bölgesel farklııklar Türkiye için değerlendirildiğinde, bölgesel düzeyde farklılaşmaların ekonomik büyüme ve kalkınmayı olumsuz etkilediği açıktır. Bu anlamda Türkiye'de bölgesel düzeyde üretimin geliştirilmesi ve bölgesel farkıkların giderilmesi için uzun yıllardan beri yatırım teşvikleri gibi temel politikalar uygulanmaktadır. Uygulanan söz konusu yatıım teşviklerinin bölgesel düzeyde etkinliğini ortaya koymak bu çalışmanın temel hedefleri arasında yer almaktadır. 
Yukarıda bahsedilen motivasyonla dizayn edilen bu ampirik çalş̧manın temel amacı, 2004-2018 döneminde Türkiye'de 26 Kalkınma Bölgesi (NUTS2) temelinde yatııım teşviklerinin bölgesel düzeyde ekonomik büyüme üzerindeki etkisini ortaya koymaktır. Araştırmanın analiz kısmında panel veri analizinden yararlanılmıştır. Analiz kısmında yatııım teşviklerinin bölgesel ekonomik büyüme ve ekonomik sektörler üzerindeki etkisini tahmin edebilmek amacıyla dört temel model üzerinden hareket edilmiştir. Öncelikle toplam yatııım teşviklerinin bölgesel ekonomik büyüme üzerindeki etkisi analiz edilmiştir. Bunun yanında tarım sektörüne verilen teşviklerin bölgesel tarım sektörü üzerindeki etkisi, hizmetler sektörüne verilen yatırım teşviklerinin bölgesel hizmetler sektörü üzerindeki etkisi ve sanayi sektörüne verilen teşviklerin bölgesel sanayi sektörü üzerindeki etkisi ayrı modeller şeklinde tahmin edilmiştir. Analiz kısmında öncelikle modellerde kullanılan serilerin durağanlıkları ve yatay kesit bağımlııkları araştııılmıştır. Buna göre modellerin tahmincisi belirlenmiştir. Bunun yanında tahmin modellerine ait yatay kesit bağımlılı̆̆ı değişen varyans ve otokorelasyon sorunları belirlenmiştir. Tüm modellerde bahsedilen sorunlar belirlendiği için tahmin edilen modellerde değişen varyans, otokorelasyon ve yatay kesit bağımlılığını ortadan kaldırarak modelleri dirençli hale getiren Panel Corrected Standart Error (PCSE) yöntemi kullanılmıştır.

Araştırma sonuçlarında elde edilen bulgular, öncelikle Türkiye'de bölgesel düzeyde toplam yatı̊ım teşviklerinin bölgesel ekonomik büyüme üzerindeki etkisinin \%1 anlamllık seviyesinde pozitif yönde olduğunu göstermektedir. Elde edilen bu sonuç Türkiye'de bölgesel düzeyde yatırım teşviklerinin etkin bir şekilde kullanıldığını göstermektedir. Özellikle milli gelir düzeyine düşük miktarlarda katkı sağlayan bölgelerin bu şekilde etkinliklerinin artırıldı̆ı ifade edilebilir. Fakat elde edilen katsayının düşük seviyelerde olması bölgesel düzeyde yatııım teşviklerinin artıııması gerektiğine işaret etmektedir. Sonuçlar ayrıca tarım sektörüne verilen yatııım teşviklerinin tarım sektörünü pozitif etkilediğini, hizmetler sektörüne verilen yatııım teşviklerinin hizmetler sektörünü pozitif etkilediğini ve sanayi sektörüne yönelik teşvik yatııımlarının da sanayi sektörünü pozitif etkilediğini göstermektedir. Teşvikler açısından değerlendirildiğinde en fazla etkinin tarım sektörü üzerinde olduğu belirlenmiştir. Türkiye'de tarım sektörünün modernleşemediği, tarım sektörünün faktör verimliliğinin düşük olduğu ve tarım ithalatının günden güne artması gibi faktörler düşünüldüğünde söz konusu olumlu etkinin uzun vadede önemli katkılarının olacağı belirtilebilir. 
Araştırmada elde edilen sonuçların, yatııım teşviklerinin etkinliğinin sağlanması ve uzun dönemli politikalar açısından çok önemli olduğu düşünülmektedir. Sonuçlar, teşvikler açısından bölgesel düzeyde verilen yatırım teşviklerinin hem etkinliklerinin hem de miktarlarının artırıması gerektiğini ortaya koymaktadır. Özellikle tarım sektöründen elde edilen sonuçlar, Türkiye'de tarım sektörünün milli gelire katkısı düşünüldüğünde, teşviklerin etkisinin hem nedensellik temelinde hem de kısa ve uzun dönemler itibariyle sonraki çalışmalarda incelenmesi gerektiğini göstermektedir. Bunun yanında sanayi ve hizmetler sektörüne verilen yatırım teşviklerinin bölgesel ekonomik büyüme üzerindeki etkisini gösteren katsaylların düşük seviyelerde olması, bu sektörlerin de sonraki çalışmalarda derinlemesine incelenmesi gerektiğini ortaya koymuştur. 